\title{
Customer Preferences in Bank Selection before and after the Pandemic in the Light of Financial Culture and Awareness
}

\author{
Ágnes Csiszárik-Kocsir, habil. Ph.D \\ Óbuda University, Bécsi út 96/b, 1034 Budapest, kocsir.agnes@uni-obuda.hu
}

\begin{abstract}
The concept of financial culture and its importance is one of the most popular topics today. Financial knowledge and awareness are necessary in every aspect of life. It is important not only when choosing a bank account type or taking out a loan, but also when conducting conscious financial activities. The recent crisis underscores the damage that can be caused by a lack of financial literacy and awareness, and the devastation that can be caused by irresponsible financial decisions. Lack of economic awareness and knowledge can cause enormous damage to the economy, lead to irresponsible economic decisions, projecting solutions over the years or even generations. This was perfectly illustrated following the 2008 crisis, with the collapse of a series of recklessly taken out credit products. More than ten years later on, a large number of research and studies have been written to promote financial literacy (Németh, 2017), but these have typically ended up in 'desk drawers', scattering any substantial progress. Even today, public education is still not equipped to effectively impart financial literacy. The lack of financial literacy was demonstrated by the crisis caused by the coronavirus epidemic. Unexpected and unforeseen closures have highlighted new aspects of financial literacy. The emergence of home-based finance has led to a reassessment of previous financial decisions, including the selection of bank service providers. The objective of this paper is to show bank selection preferences as a function of financial culture before and after the crisis by highlighting the most important factors for customer loyalty based on the results of a primary research.
\end{abstract}

Keywords: financial literacy; financial culture; financial decision; digitalisation; bank services

\section{Introduction}

Financial decisions are decisions about financial and monetary instruments that are based on sound financial knowledge. Today's homo economicus (economic man) should be able to do this in a rational and standardized way, along the lines of textbooks and theories, and based on classic characteristics. However, every day Homo sapiens in real life have limited rationality due to lack or limited knowledge and understanding. However, this limited rationality also has an impact on daily life and daily decision-making. The limited or lack of financial socialization and 
financial knowledge means that the information needed to make rational decisions cannot be obtained. The low demand for such information and lack of motivation can make the situation more complicated. One of the biggest crises of the modern era, the 2008 crisis, has highlighted the importance of financial literacy. Numerous studies and research have shown that the low-level of financial literacy and the lack of financial literacy played an important role in the prolonged [1]. Financial decisions made as a result of for-profit banking practices with no financial literacy have put many financial institutions on the verge of bankruptcy, collapse and failure. The resulting crisis has led governments to seek solutions to the situation, aimed at stabilizing markets but also undermining confidence in the banking system. More than ten years after the economic crisis, knowledge of finances, money and related skills has become increasingly important, almost part of our lives. Nevertheless, the theoretical and practical financial competence of Hungarian households and companies still lags behind in an international comparison [2] [3] [4] With the advent of FinTech companies, banks are spurring innovation to add useful elements and digital support to banking. Until the 2000s, the banking sector was considered one of the most innovative sectors. This was reflected in digitalization, the proliferation of digital solutions, customer experience, and convenience services. However, the emergence of high-tech and FinTech companies after the turn of the millennium pushed traditional banks into the background, exacerbated by the lack of resources and liquidity due to the crisis [5]. According to some studies, the main purpose of banks during this period is not innovation and innovation, but mitigation of damage [6] [7], resulting in a huge loss of blood. Efforts to minimize losses and relieve loans that had failed deprived companies of energy for innovations and left room for FinTech companies to demonstrate their motivation and ability to innovate. FinTech companies have penetrated the market for common banking services such as account management and payment services, but also for investments, loans and insurance. FinTech companies that can innovate on a daily basis mean a challenge for traditional banking systems to catch up with them [8] [9]. The banking system is a very tightly and widely regulated sector, leading to more stringent operations and actions compared to their agile competitors. That is why the banking system faced the new challenge of competing with FinTech companies after recovering from the effects of the crisis. The innovative solutions implemented by banks are responding to market changes, but they are doing so more inflexibly and with a delay compared to their peers that are dictating the competition. This is why customer segmentation, the development of customised service offerings, the expansion of time-saving digital transactions and the reduction of bank waiting times have become important activities in order to meet the expectations of their [10]. The coronavirus pandemic, which escalated in 2020, and the subsequent closures and tightening of regulations, has only reinforced the situation described above. The present study also explores this issue while seeking to answer the question of which factors play a role in selecting a bank, what factors serve as the basis for the selection of a bank by each customer group by highlighting the main correlations and influencing factors. 


\section{Literature Review}

\subsection{A Diverse Approach to Financial Culture from the Turn of the Millennium to the Present}

Individual cultural characteristics are formed through learning and socialization. This is no different for financial culture and financial attitudes. It takes decades for a behaviour pattern to become part of a culture. In this process, the family plays a very important role. A number of studies have shown that the younger generation learns about money management, attitudes, aspects and risk-taking behaviour patterns from their parents, and the family is the main source of this information and shaping their attitudes [11] [12]. In view of this, we should first clarify the concept of financial socialization in the context of financial culture. Financial socialization is the ability to acquire all relevant theoretical, behavioral, emotional and material information that contributes to personal financial knowledge, skills and abilities. The main source is the family, the group of relatives and friends, supplemented by professional organizations and educational institutions [13]. The influence of the media should also be added to the above list [14]. Inherited patterns are incorporated into financial decisions, shaping individuals' attitudes towards money and the way they deal with financial issues, which is embodied in both attitudes towards banking and money management. Personal responses to certain stimuli are shaped by financial experience, which further reinforces the importance of financial socialisation [15]. Gutter et al [16] emphasized in their paper that individuals acquire financial skills in society and learn from them, making people who we live together with an authoritative model. Due to the abundance of money and perceived unlimited resources before the crisis, certain age groups were socialized without understanding the value of money or knowing its value, because they were told through various channels that the wealth they wanted can be obtained through obtaining loans. In the run-up to the crisis, Johnson and Sherarden [17] pointed out that the younger generation needs to be involved in the preparation of the financial process through the education system or when planning the family budget. Osana and his colleagues [18] have expressed similar views before. They argued that this would give young people a greater sense of responsibility.

If we want to look at a single definition of financial culture, it is important to note that there is no universally accepted and inclusive definition. The definition of financial literacy is served by the agreement on the development of financial literacy reached between the National Bank of Hungary and the then, State Financial Supervisory Authority (FSA) in April 2008 on the development of financial literacy prior to the crisis as "the level of financial knowledge and skills that enables individuals to identify and, once acquired, interpret the basic financial information necessary to make informed and prudent decisions and to make decisions on that basis, assessing the possible future financial and other consequences of their decisions". This definition was expanded by the crisis and subsequent recession [19]. 
Atkinson and Messi [20] define financial literacy as the set of knowledge, skills, abilities, attitudes and forms of behaviour that are required to make sound financial decisions, both individually and in the community. According to Béres and Huzdik [21] financial literacy refers to financial knowledge (financial literacy), financial knowledge and experience, financial skills and financial awareness and should be understood in combination. Holia and Iramani [22] defined financial literacy in terms of behaviour. In their opinion, it can be conceptualized in terms of a person's attitude towards day-to-day finances (financial planning, budgeting, control, spending, money management and savings).

Luksander et al. [23] define financial literacy as the ability to process financial information and make sound financial decisions. Suganya and co-authors [24] see the essence of financial literacy as a set of knowledge for individuals to maximize their lifetime financial well-being. According to Süge [25], the concept of financial literacy contains all the elements that help people navigate financial issues and thereby generate their financial well-being. Amagir and colleagues [26] define financial culture as a combination of three elements. They define it as a combination of knowledge, behavioral patterns and attitudes. The author also defines several factors in financial culture and attitudes towards finance in different ways from the perspective of behavioral economics. According to Mien and Thao [27], financial behaviour is determined by attitudes, knowledge and external control. In our model [28], which is based on these findings, we interpret financial literacy as a combination of three factors.

\section{Financial knowledge, professional knowledge}

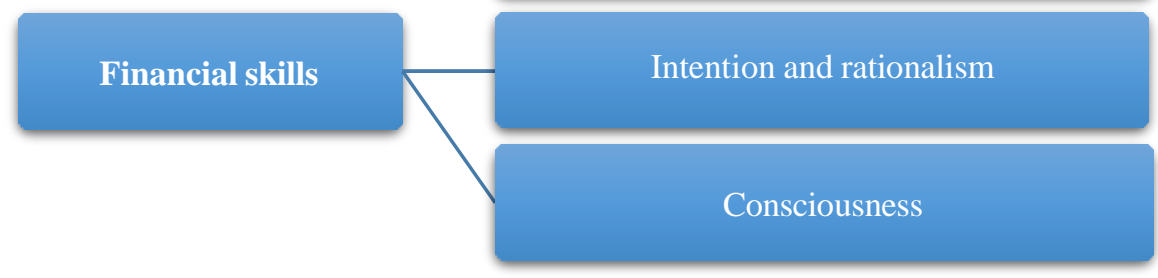

Figure 1

The components of financial capability that define financial culture

Source: Csiszárik-Kocsir et al., 2016

In terms of financial literacy, it is definitely a combination of skills, abilities, knowledge and behavioral factors that can enhance personal happiness and wellbeing, improve their sense of security, and enable them to make rational decisions. There is a consensus in the profession that financial socialization is essential to financial literacy, so education is inevitable. This research also aims to study its role in influencing financial education. This is why Grifoni and Messy [29] capture the essence of this concept as an indispensable skill today. Compared with a few years 
ago, today's individuals and families need more skills [30]. Several studies have addressed the role of education in financial awareness [31] [32]. Such knowledge has become indispensable for individuals who know and understand modern financial processes and are able to adapt to change. Basic financial literacy imparted by educational institutions has a positive impact on responsible financial decisions [33] [34], but it has also been shown that good basic financial literacy does not in itself lead to good financial decisions, as it requires an individual's attitude [35] [17]. Financial literacy is also reflected in making the right life- long decisions such as saving for retirement, but it also includes saving, investing and borrowing. Financial literacy improves retirement planning, the ability to prepare for retirement in a thoughtful way [36], and the ability to rationally manage savings, stock market and bank investments [37]. The acquisition of financial knowledge should thus be seen as a long-term investment.

Low levels of financial literacy have been a problem in our country for many years. Despite numerous studies and initiatives, research has shown little success. Research data on the financial culture of OECD countries, which have been identified by many researchers, continue to point to shortcomings in our country. The 21 points assigned to three factors studied by the OECD: knowledge (0-7 points), behaviour (0-9 points) and attitude (1-5 points) places Hungary in the lower middle category. In the 2016 measurement, we scored 12.5 points, which, while not increasing for the next measurement in 2018 as a result of numerous awarenessraising programmes, initiatives and research, decreased slightly. Countries that can be seen as direct competitors or neighbours, such as Austria, which is almost two points higher than our country (14.2-14.4), the Czech Republic, which is at a similar level to us (12.5-12.9), Poland, which started from a lower level, but has jumped enormously (11.6-13.1), or Croatia, which has a lower score than us (12.1-12.3), have also improved their ranking in recent years. All this shows that Hungary has room for improvement in terms of financial culture, knowledge, behaviour and attitudes.

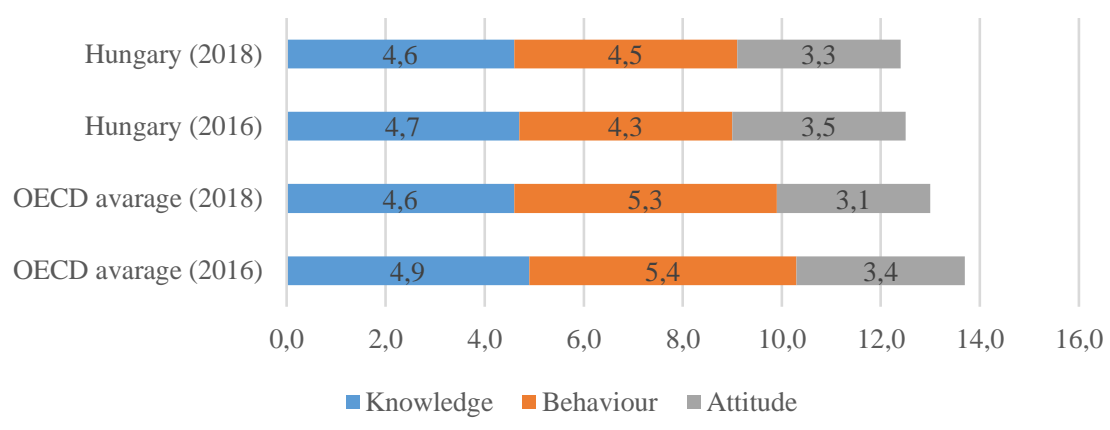

Figure 2

The state of financial culture according to the OECD survey

Source: author's own editing based on [38] [39] 
As with all decisions, there are costs and benefits. Several studies have investigated the long-term benefits of investing in financial knowledge. Japelli and Padula [40] concluded that individuals who invest in financial education can enjoy higher wealth growth than individuals who do not. They also showed a positive relationship between wealth growth and financial literacy.

Financial education is most effective if it points out practical aspects that assist the individual to react immediately in certain situations. Demonstrating through practical examples is much better in terms of retaining knowledge. Several studies have shown that people who have been involved in financial product decisionmaking from a young age will certainly have greater awareness of these issues when they grow up [41]. Programmes aimed at raising financial awareness mainly focus on household budgeting, savings management, and borrowing. Unfortunately, banking services receive little attention in the curriculum. And it is exactly on this area that the coronavirus epidemic has had an impact and reduced the financial security of individuals and families [42], which could have been improved by the knowledge that individuals gained from knowing more about financial services, quasi-lifebelts.

\subsection{The Combined Impact of Financial Awareness and Digitalisation on the Banking System in the Light of the Pandemic}

With the exception of the 2008 crisis, the rise of digitalization has most prominently highlighted the importance of financial knowledge. Although the banking system recovered very slowly from the 2008 crisis, it is still working hard to restore stability and establish a credible image of itself, the companies that emerged in the background could quickly and effectively respond to new customer needs due to their agility. The banking system, squeezed by the crisis, had almost no development resources before the mid-2010s, leaving room for innovative new market players. Since the mid-2010s, smartphones have become more popular, and the scope of online transactions has also expanded. Along these processes, the banking system recognised that it had to learn from new competitors, and vice versa. The disappearance of national borders through digitalisation, the ever-expanding range of financial products and the emergence of FinTech companies have laid the new foundations for assessing traditional banking services. The digitisation of financial services has been ongoing for several years, gradually bringing many areas of banking online, from day-to-day financial management to account management [43].

Hatami [44] outlines five options in connection with the future of banks (cited in [45]):

- "A better bank": they have recognized challenges, tailored operations to the clients' needs, connected with customers via digital channels, 
retained the majority of their customers, and equipped their staff to meet the new challenges.

- $\quad$ "New bank": the old banks have lost out to the competition, as they have lost some customers, who have flocked to new, faster, more agile banks that can serve their needs better.

- "Shared banking": new businesses have emerged in parallel with competitors, carving out a slice of traditional banking businesses. They do not want to act as a bank, leaving room for classic institutions, but only providing specific activities to their customers.

- $\quad$ "Background bank": they provide only back-up support, supervision and licensing, with significant risk-taking.

- $\quad$ "Disintermediated bank": customers, disliking their bank, increasingly switched more banking services to their preferred providers. In their case, they felt they were more trusted and less abused than their banks. However, in the background, banks are still at work, providing services but no longer owning their customers.

Most banks have realized that it is difficult to keep up with the agile FinTech companies with huge innovation capabilities. $81 \%$ of European banks believe this is an appropriate step to collaborate with them to innovate systems and processes, $8 \%$ are considering developing them independently, $6 \%$ are considering outsourcing their core processes, and the remaining $5 \%$ consider it suitable to create their own neobank (MNB, 2020). All of this shows that banks see the importance of digital challenges and are considering solutions to ensure that the best solution is the above-mentioned scenario. Responding to digitalisation challenges requires not only rapid technological development or unpredictable events, but also generational changes.

As the younger generation grows, the need for digitalization will continue to increase. Visiting a bank branch seems like an extreme activity for Generation Z, who is called the "always online" generation, but the late Generation X and Y, who dominate the world of work, have the same policy. The pandemic has even reinforced this. However, the demand for digital solutions also varies greatly with individual financial literacy, risk tolerance, age and education. An Accenture 2019 survey [47] categorized bank customers and distinguished the following four types.

- Pioneers: who are risk-takers, open and receptive to innovative solutions and not intimidated by technology. They are mostly Generation $\mathrm{Z}$ and late Generation $\mathrm{Y}$ young people, whose lives are dominated by mobile phones and a constant online presence. They are eager to try new things, new channels, but also to take risks for greater rewards.

- Pragmatists: they see technology as a tool, they do not live their lives in the expansion of digital platforms. They are completely satisfied 
with the services provided by their banks, they are not open to new things, but if banks personalise them for them, they welcome it.

- Sceptics: they cannot accept such an advance in technology. They are cautious, not to be persuaded by a service, suspicious, difficult and conscious customers for banks. They are Generation Y, the strategic base for banking.

- Traditionalists: they are people centred. They focus on the person, not the convenience of novelty. Typically, they are members Generation BB and X. They are sceptical, suspicious and not very satisfied with the activities of financial service providers.

The outbreak of the coronavirus epidemic in 2020 and its aftermath has only reinforced this trend. Accenture's 2020 report [48] on digital channel usage published the following statistics before and after the pandemic. The graph shows the channels through which customers interacted with their banks.

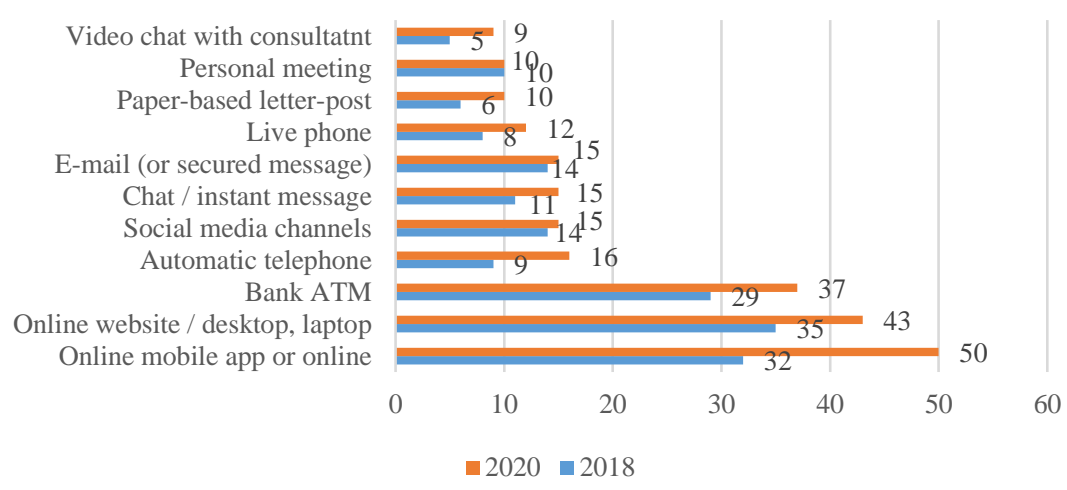

Figure 3

Use of digital channels before and after the pandemic (\%)

Source: author's own editing based on [48]

The figure above is a perfect illustration of coercive digitalisation and its advancement. However, the domestic banking system is still in the midst of progress. As a result of the pandemic, loss aversion occurred again, depriving major development projects of resources. In parallel with the banking system, domestic FinTech companies are gaining strength in specific areas, posing a real threat to slow-moving banks.

The figure below shows the distribution of domestic FinTech firms by service, as a way of concluding the theoretical overview and setting the scene for related research. 


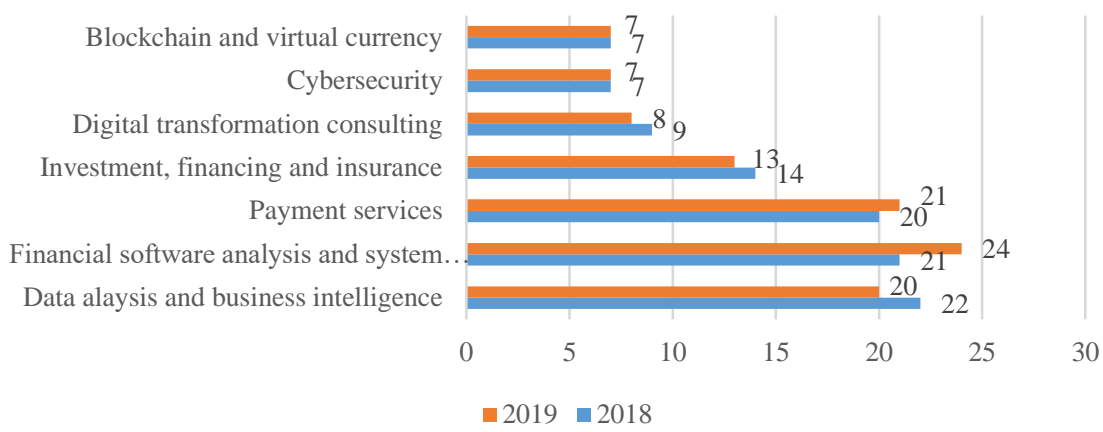

Figure 4

Distribution of FinTech companies by range of services (\%)

Source: author's own editing based on [46] [49]

\section{Material and Method}

After introducing the subject through literature review as a form of secondary research, this article presents the results of primary research carried out in 2020 . The study was conducted using pre-tested standardized questionnaires. The sample of respondents was recruited using a snowball method, resulting in the present sample of 6804 respondents presented in the paper. The questionnaire was the result of a prior, preliminary qualitative research. The research instrument contained only closed questions for better evaluation. Based on the experience of the previous surveys prior to the research, the present form of the questionnaire was developed, covering several aspects of financial awareness (attitudes, money management, bank selection, staying loyal to a bank, competencies) in the context of the coronavirus pandemic. Data collection took place between May and August 2020. The survey was conducted online, ensuring respondents' anonymity. The sample is not considered representative, but it provides the opportunity to lay the foundations for a future representative study. The results of the questionnaire presented in this study were obtained using SPSS 22.0 software. The obtained results are presented according to whether the respondent had previously participated in financial education.

The literature review stressed the importance of financial literacy. This is becoming more and more important due to the need for digitalization. This paper seeks to answer the question of how well these factors are reflected in the views of domestic respondents. In line with the literature review above, this paper seeks to answer the question of how participation in former financial education affects customer preferences and what factors determine the selection of an individual banking 
service provider together with the fact of how these preferences have changed as a result of the pandemic. The paper tests the following hypotheses.

H1: The pandemic has also increased the need for digitalisation among respondents, which is stronger for individuals who are financially educated beforehand.

H2: Respondents who have previously received financial education have not selected and do not choose a financial service provider on emotional grounds.

Men accounted for $50.5 \%$ of the sample and $49.5 \%$ of the respondents were women. In terms of educational attainment, $7.1 \%$ of respondents had primary education, 57.4\% had secondary education, 26.2\% had BSc title and 9.3\% had MSc. $43.1 \%$ (2934) of the sample had previously participated in financial education, while the other half of the sample, $56.9 \%$ (3870), had not participated in financial education prior to responding. Cross tabulation analysis, calculation of Chi-squared values and adjusted standardised residual values are used to evaluate the responses.

\section{Results}

The questions raised in this article are intended to answer the extent to which previous financial education has affected customers' selection of banks. In terms of the factors presented, a separate question examines the changes before and after the coronavirus pandemic. Based on the views of the interviewees, the possible answers include the factors that were most frequently raised in the qualitative research before the questionnaire. In this study, the term "pre-pandemic" refers to the period before the lockdown due to the 2020 pandemic and the period before the setback due to the coronavirus pandemic, while the term "post-pandemic" refers to the period after the economic recovery after the pandemic, the period after the temporary normalisation of the situation. The following factors were included in the questionnaire with regard to the selection of banks.

- The speed of banking,

- Opening hours of the bank,

- The price of the services offered by the bank,

- The banking services of the residence,

- The range of online, home-based services offered by the bank,

- The expertise of the bank teller,

- The kindness of the bank teller,

- The reputation of the bank and

- Reliability of the bank. 
The first thing to look at is the frequency of responses, which is illustrated in the figure below, showing the results as a percentage of responses.

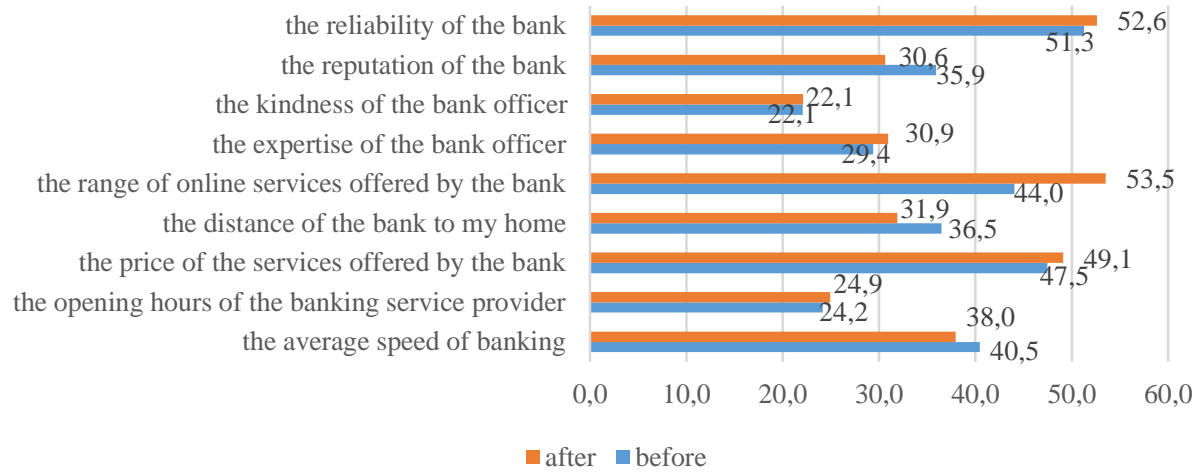

Figure 5

Perception of factors influencing bank selection before and after the pandemic (\% of respondents)

Source: author's own research and compilation, 2020, $N=6804$

The frequency of each response shows that bank reliability was the main criterion for selecting a bank before the epidemic (51.3\%). The background of financial socialization is clearly manifested here, since the reliability of banks is, first of all, one of the pieces of information that comes from the circle of people we consider. The opinions of friends, family and relatives are the main source of information for assessing the reliability of a bank, followed by objective information from professional or other sources. The price of banking services was ranked second (47.5\%), where again respondents' financial awareness is shown by respondents. Third place was given to the range of services available online, from home (44\%) in terms of perceptions before the epidemic. A less important factor for respondents before the crisis was the friendliness of the bank teller, the opening hours of the branch, or even the competence of the bank teller.

After the crisis, online services were clearly the first choice for banks (53.5\%). Literature reviews show that this is a dangerous factor for banks, as FinTech companies are at the forefront of this issue, as opposed to bank players who have been shrugging off the effects of the pandemic. They can move services to online platforms that banks currently cannot. This factor will not change in the future, as the risk of the same kind of closure that we saw in 2020 will arise from time to time. Reliability (52.6\%), which was previously ranked first, is second only due to the coronavirus pandemic, up 1.3 percentage points on the previous result, reflecting respondents' fears. The third place was for the cost of services $(49.1 \%)$, which, although small, is an indication of the loss of income due to the pandemic and the worsening of the living conditions of certain groups. Even less important in the selection of a bank after the pandemic is the kindness of the person in charge, just 
as the opening hours of the branch are not important, as much more rational factors dominate respondents' preferences. The results are examined in more detail in the two tables below.

Table 1

Bank selection preferences and their change in relation to previous financial education before the pandemic

\begin{tabular}{|l|c|c|c|c|c|}
\hline & total & $\begin{array}{c}\text { with } \\
\text { previous } \\
\text { financial } \\
\text { education } \\
\mathrm{N}=2934\end{array}$ & difference & $\begin{array}{c}\text { without } \\
\text { previous } \\
\text { financial } \\
\text { education } \\
\mathrm{N}=3870\end{array}$ & difference \\
\hline the average speed of banking & 40.5 & 41.1 & 0.6 & 40.0 & -0.5 \\
\hline $\begin{array}{l}\text { the opening hours of the banking } \\
\text { service provider }\end{array}$ & 24.2 & 23.8 & -0.4 & 24.4 & 0.3 \\
\hline $\begin{array}{l}\text { the price of the services offered by } \\
\text { the bank }\end{array}$ & 47.5 & 50.3 & 2.8 & 45.3 & -2.2 \\
\hline $\begin{array}{l}\text { the distance of the bank to } \\
\text { residence }\end{array}$ & 36.5 & 36.4 & -0.1 & 36.6 & 0.1 \\
\hline $\begin{array}{l}\text { the range of online services } \\
\text { offered by the bank }\end{array}$ & 44.0 & 48.9 & 4.9 & 40.3 & -3.7 \\
\hline the expertise of the bank teller & 29.4 & 27.9 & -1.5 & 30.5 & 1.1 \\
\hline the kindness of the bank teller & 22.1 & 20.7 & -1.4 & 23.1 & 1.1 \\
\hline the reputation of the bank & 35.9 & 40.2 & 4.2 & 32.7 & -3.2 \\
\hline the reliability of the bank & 51.3 & 56.2 & 4.9 & 47.5 & -3.7 \\
\hline
\end{tabular}

Source: author's own research and compilation, 2020, $N=6804$

The table displays the factors that are much more prevalent among respondents who have studied finance in the past compared to the sample. In terms of selecting a bank, before the pandemic there was a stronger demand for the reliability and perception of the bank, as well as a higher demand in terms of the services provided and the price and speed of banking. Respondents who had not previously studied finance showed a stronger emotional need for the kindness and expertise of the bank officer (teller). The distance from the branch and its opening hours is also an important factor, so convenience is the main consideration. The facts above reflect the previously envisionaged financial consciousness, and those who have previously gained financial education seem to have chosen a financial service provider on the basis of more rational considerations, compared to less financially educated respondents, where convenience and emotional considerations were more dominant.

Regarding the post-pandemic aspects, the same four factors were more strongly represented for better educated respondents although the difference was reduced in terms of sample mean. A new factor also emerged, namely, the need for the expertise of a bank teller, which became more important for respondents who had previously studied finance. 
Table 2

Bank selection preferences and their change in relation to previous financial education after the pandemic

\begin{tabular}{|l|c|c|c|c|c|}
\hline & total & $\begin{array}{c}\text { with } \\
\text { previous } \\
\text { financial } \\
\text { education } \\
\text { N=2934 }\end{array}$ & difference & $\begin{array}{r}\text { without } \\
\text { previous } \\
\text { financial } \\
\text { education } \\
\text { N=3870 }\end{array}$ & difference \\
\hline the average speed of banking & 38.0 & 39.5 & 1.6 & 36.8 & -1.2 \\
\hline $\begin{array}{l}\text { the opening hours of the banking } \\
\text { service provider }\end{array}$ & 24.9 & 22.5 & -2.4 & 26.8 & 1.8 \\
\hline $\begin{array}{l}\text { the price of the services offered by } \\
\text { the bank }\end{array}$ & 49.1 & 52.4 & 3.3 & 46.6 & -2.5 \\
\hline the distance of the bank to residence & 31.9 & 31.8 & 0.0 & 31.9 & 0.0 \\
\hline $\begin{array}{l}\text { the range of online services offered } \\
\text { by the bank }\end{array}$ & 53.5 & 57.0 & 3.5 & 50.9 & -2.6 \\
\hline the expertise of the bank teller & 30.9 & 31.6 & 0.7 & 30.4 & -0.5 \\
\hline the kindness of the bank teller & 22.1 & 20.2 & -1.9 & 23.5 & 1.4 \\
\hline the reputation of the bank & 30.6 & 33.9 & 3.3 & 28.1 & -2.5 \\
\hline the reliability of the bank & 52.6 & 56.4 & 3.8 & 49.7 & -2.9 \\
\hline
\end{tabular}

Source: author's own research and compilation, 2020, $N=6804$

For respondents with no financial education, the latter factor was not significant, and they kept on considering the purely convenience aspects where they showed high values (friendliness, distance, opening hours).

The following part examines whether there is a statistically measurable relationship between previous participation in financial education and bank selection, and which groups perform above or below the expected level. For this purpose, Chi-square values are calculated and adjusted standardised residual values (AdjR) are also examined.

Prior to the pandemic, there was no statistically verifiable correlation between bank selection criteria and previous financial education for only three factors. Therefore, previous financial education has no statistically verifiable impact on selecting a bank branch based on distance, business hours, or speed of banking. More respondents with previous financial education than expected selected the price of services, the range of services available online, the reliability of the bank, and the perception of the bank as determining factors. Respondents without financial education prioritized more than expected the kindness and expertise of bank employees. Therefore, what was previously assumed was statistically confirmed, i.e., having financial knowledge makes us more rational in selecting a bank than not having it, when decisions are made on emotional considerations. 
Table 3

Bank selection preferences associated with previous financial education before the pandemic

\begin{tabular}{|l|c|c|c|}
\hline & & $\begin{array}{c}\text { AdjR } \\
\text { with } \\
\text { previous } \\
\text { financial } \\
\text { education } \\
\mathrm{N}= \\
2934\end{array}$ & $\begin{array}{c}\text { AdjR } \\
\text { without } \\
\text { previous } \\
\text { financial } \\
\text { education } \\
\mathrm{N}=3870\end{array}$ \\
\hline $\begin{array}{l}\text { Chi- } \\
\text { square } \\
\text { provider }\end{array}$ & 0.358 & 0.9 & -0.9 \\
\hline the price of the services offered by the bank & 0.000 & -0.6 & 0.6 \\
\hline the distance of the bank to residence & 0.890 & 4.1 & -4.1 \\
\hline the range of online services offered by the & 0.000 & -0.1 & 0.1 \\
\hline bank & 0.532 & 7.1 & -7.1 \\
\hline the expertise of the bank teller & 0.018 & -2.4 & 2.4 \\
\hline the kindness of the bank teller & 0.016 & -2.4 & 2.4 \\
\hline the reputation of the bank & 0.000 & 6.4 & -6.4 \\
\hline the reliability of the bank & 0.000 & 7.1 & -7.1 \\
\hline
\end{tabular}

Source: author's own research and compilation, 2020, $N=6804$

Table 4

Bank selection preferences associated with previous financial education after the pandemic

\begin{tabular}{|l|c|c|c|}
\hline & Chi-square & $\begin{array}{c}\text { AdjR with } \\
\text { previous } \\
\text { financial } \\
\text { education } \\
\mathrm{N}=2934\end{array}$ & $\begin{array}{c}\text { AdjR without } \\
\text { previous } \\
\text { financial } \\
\text { education } \\
\mathrm{N}=3870\end{array}$ \\
\hline the average speed of banking & 0.020 & 2.3 & -2.3 \\
\hline $\begin{array}{l}\text { the opening hours of the banking service } \\
\text { provider }\end{array}$ & 0.000 & -4.0 & 4.0 \\
\hline $\begin{array}{l}\text { the price of the services offered by the } \\
\text { bank }\end{array}$ & 0.000 & 4.8 & -4.8 \\
\hline the distance of the bank to residence & 0.945 & -0.1 & 0.1 \\
\hline $\begin{array}{l}\text { the range of online services offered by the } \\
\text { bank }\end{array}$ & 0.000 & 5.0 & -5.0 \\
\hline the expertise of the bank teller & 0.283 & 1.1 & -1.1 \\
\hline the kindness of the bank teller & 0.001 & -3.2 & 3.2 \\
\hline the reputation of the bank & 0.000 & 5.2 & -5.2 \\
\hline the reliability of the bank & 0.000 & 5.5 & -5.5 \\
\hline
\end{tabular}

Source: own research and compilation, 2020, $N=6804$ 
In two cases, no correlation could be found along the lines of the data-based change in preferences following the pandemic. Previous financial knowledge does not affect the perception of proximity to a bank branch and does not correlate with the knowledge of the bank teller. Before the pandemic, the latter one was also a factor, but the speed of service was not. Service speed was an interesting factor in the aftermath of the pandemic, as it statistically confirmed the fact that respondents wanted to spend as little time as possible in the branch during the lockdown due to fear of infection. All other factors were also statistically correlated with previous financial knowledge. Respondents with previous financial awareness outperformed the expectations in terms of speed of banking, price of services, range of online services, reliability and perception of the bank. For those without previous financial knowledge, convenience continues to prevail such as the opening hours of the bank branch and the friendliness of the branch manager. These values performed above expectations.

\section{Summary}

By means of the secondary and primary data analysis provided, the research sought to answer the question of to what extent financial knowledge and previous financial education acquired affect the selection of financial service providers. The skills and abilities acquired through financial socialization are incorporated into our everyday behaviour to encourage individuals to make more rational decisions. The accelerated digitalization process in the $21^{\text {st }}$ Century has left no economic sectors unaffected. Until the millennium, financial services have been at the forefront of the digital process. However, the mortgage crisis a few years ago has completely changed the situation. Loss aversion and damage mitigation divert the attention and resources of digital projects. Taking advantage of this market niche, financial technology companies have emerged to provide cheaper and better banking services through digital platforms. Just as the development of culture is the result of a long process over decades, digitalisation efforts take time to become a stimulus for all generations.

Research has indicated that previous financial knowledge will indeed guide consumers to make more rational decisions. With awareness, objective and measurable factors dominate. When we are financially aware, the perception of the bank, the range and price of its services and the digital services matter when choosing a bank. On the other hand, decision makers with no financial education and background tend to focus on convenience. These trends have become more pronounced during the pandemic. The importance of increasing demand for digital services, the drive for reliability, and the reduction of face-to-face interactions due to infection risks are obvious. All these factors confirm the hypotheses proposed in this study. Statistical evidence shows that the pandemic has triggered greater consumer demand for digitization, which justifies the first hypothesis. The research has also confirmed that, due to previous financial education, financial culture and financial awareness are pushing the emotional factors of bank selection into the background, giving way to rational decision-making. All this suggests that financial 
education is necessary. Formal and non-formal education, in addition to the immediate environment, plays an important role in this regard. More and more people are aware of this, and more and more programmes are incorporating this message. It is a cause for some optimism, which has greatly contributed to the improvement of the criticized financial culture of the Hungarians.

\section{References}

[1] Kovács, L.; Sütő, Á.: Megjegyzések a pénzügyi kultúra fejlesztéséről. Gazdaság és Pénzügy. Vol. 7, No. 1, 2020, pp. 137-146

[2] Bárczi, J.; Zéman, Z.: A pénzügyi kultúra és annak anomáliái. Polgári Szemle. Vol. 11, No. 1-3, 2015, pp. 72-80

[3] Varga, J.: Bases for organizational development: How to become a more competeitve company?. $2^{\text {nd }}$ Business \& Enterprenurial Conference, Zagreb (ed: Kolakovic, M.), pp. 15-15

[4] Sági, J.; Vasa, L.; Lentner, Cs.: Innovative Solutions in the Development of Households' Financial Awareness: A Hungarian Example. Economics and Sociology, 2020, Vol. 13, No. 3, pp. 27-45

[5] Lentner, Cs.; Kolozsi, P. P.: Old Problems in a New context - Excerpts from the New Ways of Thinking in Economics after the Global Financial Crisis. Economics \& Working Capital, 2019, No. 1-2, pp. 53-62

[6] de Grauwe, C.: The Banking Crisis: Causes, Consequences and Remedies. CEPS Policy Brief. No. 178, 2008, http://aei.pitt.edu/11706/1/1758.pdf, downloaded: 23 April 2014

[7] Calomiris, C.W.: The past mirros: notes, surveys, debates - The banking crisis yesterday and today. Financial History Review. Vol. 17, No. 1, 2010, pp. 3-12

[8] Pintér, É.; Bagó, P.: Digitlizáció hatása a FinTech szektorra. Vállalkozásfejlesztés a XXI. században 2020/1 (ed.: Csiszárik-Kocsir, Á., Varga, J.), pp. 289-304

[9] Bagó, P.; Pintér, É.: FinTech ázsiai módra. Vállalkozásfejlesztés a XXI. században 2019/1 (ed.: Csiszárik-Kocsir, Á., Varga, J.), pp. 189-200

[10] Baranyi, A.; Széles, Zs.: A hazai lakosság megtakarítási hajlandóságának vizsgálata. Bulletin of the Szent István University Special Issue Part II, 2008, pp. 367-378

[11] Németh, E.; Béres, D.; Huzdik, K.: The Attitude of Young Hungarian Adults to Loans. Journal of Business and Social Science. 2015, Vol. 6, No. 4, pp. 63-74

[12] Németh, E.: Pénzügyi kultúrát fejlesztő képzések: felmérés és diagnózis. Új Pedagógiai Szemle. 2017, No. 7-8, pp. 46-68 
[13] Tezel, Z.: Financial Education for Children and Youth. in: Handbook of Research on Behavioral Finance and Investment Strategies: Decision Making in the Financial Industry (ed.: Copur, Z.), IGI Globar Publisher, 2015, pp. 69-92

[14] Koonce, J. C.; Mimura, Y.; Mauldin, T. A.; Michael Rupured, A.; Jordan, J.: Financial information: is it related to savings and investing knowledge and financial behavior of teenagers? Journal of Financial Counseling and Planning, 2008, No. 19, pp. 19-28

[15] Schmitt, B. H.: Experiential Marketing: How to Get Customers to Sense, Feel, Think, Act, Relate to Your Company and Brands. New York: The Free Press. 1999

[16] Gutter, M. S.; Garrison, S.; Copur, Z.: Social learning opportunities and the financial behaviors of college students. Family and Consumer Sciences Research Journal, 2010, No. 38, pp. 387-404

[17] Johnson, E.; Sherraden, M. S.:From financial literacy to financial capability among youth. Journal of Sociology and Social Welfare, 2007, Vol. 34, No. 3, pp. 119-145

[18] Osana, H. P.; Tucker, B. J.; Bennett, T.: Exploring adolescent decision making about equity: structured problem solving in social studies. Contemporary Educational Psychology, 2003, Vol. 28, pp. 357-383

[19] National Bank of Hungary and the then State Financial Supervisory Authority: Együttmüködési megállapodás a pénzügyi kultúra fejlesztés területén, 2008 https://www.mnb.hu/letoltes/0415mnbpszafmegallpodaspenzugyi-kultura-fejleszte.pdf, downloaded: 09 January 2019

[20] Atkinson, A.; Messy, F. A.: Measuring Financial Literacy, OECD Working Papers on Finance, Insurance and Private Pensions No. 15, http://www.oecdilibrary.org/docserver/download/5k9csfs90fr4-

en.pdf?expires $=1498684984 \& \mathrm{id}=\mathrm{id} \&$ accname $=$ guest $\&$ checksum $=\mathrm{C} 5 \mathrm{~B} 34 \mathrm{D}$ F2381775999E9EFC9A4A5B956D, downloaded: 07 June 2020

[21] Béres, D.; Huzdik, K.: A pénzügyi kultúra megjelenése makrogazdasági szinten. Pénzügyi Szemle, 2012, No. 2, pp. 322-336

[22] Kholilah, N. A.; Iramani, R.: Studi Financial Management Behavior Pada Masyarakat Surabaya. Journal of Business and Banking, 2013, Vol. 3, No. 1, pp. $69-80$

[23] Luksander, A.; Béres, D.; Huzdik, K.; Németh, E.: A felsőoktatásban tanuló fiatalok pénzügyi kultúráját befolyásoló tényezők vizsgálata. Pénzügyi Szemle, 2014, Vol. 59, No. 2, pp. 237-258

[24] Suganya, S.; Sakthivelrani, S.; Durai, K.: Development and validation of financial literacy scale. International Journal of Research in Commerce and Management, Vol. 4, No. 1, pp. 99-104 
[25] Süge, Cs.: A pénzügyi kultúra mérhetősége. in: Tudományos Mozaik 7. II. kötet (ed.: Tompáné Daubner, K.; Miklós, Gy.) Kalocsa, Tomori Pál Főiskola, pp. 1-11

[26] Amagir, A.; Groot, W.; Maassen van den Brink, H.; Wilschut, A.: A review of financial-literacy education programs for children and adolescents. Citizenship, Social and Economics Education, 2018, Vol. 17, No. 1, pp. 5680

[27] Mien, N. T. N.; Thao, T. P.: Factors Affecting Personal Financial Management Behaviors: Evidence from Vietnam. Proceedings of the Second Asia-Pacific Conference on Global Business, Economics, Finance and Social Sciences, 2015, pp. 10-12

[28] Csiszárik-Kocsir, Á.; Varga, J.; Fodor, M.: The vale based analysis of the financial culture. The Journal of Macro Trends in Social Science, 2016, Vol. 2, No. 1, pp. 89-100

[29] Grifoni, A.; Messy, F. A.: Current Status of national Strategies for Financial Education; a comparative analysis and relevant practices, OECD Working Papers on Finance, Insurance and Private Pensions, 2012, No. 16

[30] Lusardi, A.; Mitchell, O. S.: Financial literacy around the world: an overview. Journal of Pension Economics and Finance, 2011a, No. 10, pp. 497-508

[31] Zsótér, B.: A fiatal felnőttek pénzügyi kultúrájának vizsgálata. Pénzügyi Szemle, 2018, No. 1, pp. 39-54

[32] Németh, E; Vargha, B.T.; Domokos, K.: Pénzügyi kultúra - kik, kiket és mire képeznek? - Összehasonlító elemzés 2016-2020. Pénzügyi Szemle, 2020, No. 4, pp. 554-582

[33] Chen, H.; Volpe, R. P.: An analysis of personal financial literacy among college students. Financial Services Review, 1998, Vol. 7, No. 2, pp. 107128

[34] Lusardi, A.; Mitchell, O. S.: Baby boomer retirement security: The role of planning, financial literacy, and housing wealth. Journal of Monetary Economics, 2007, Vol. 54, pp. 205-224

[35] Borden, L. M.; Lee, S.; Serido, J.; Collins, D.: Changing college students' financial knowledge, attitudes, and behavior through seminar participation. Journal of Family and Economic Issues, 2008, Vol. 29, No. 1, pp. 23-40

[36] Lusardi, A.; Mitchell, O. S.: Financial literacy and retirement planning in the United States. Journal of Pension Economics and Finance, 2011b, No. 10, pp. 509-525

[37] Van Rooij, M.; Lusardi, A.; Alessie, R.: Financial literacy, retirement planning and household wealth. The Economic Journal, 2012, No. 122, pp. 449-478 
[38] OECD: G20/OECD INFE report on adult financial literacy in G20 countries. 2017, https://www.oecd.org/daf/fin/financial-education/G20-OECD-INFEreport-adult-financial-literacy-in-G20-countries.pdf, downloaded: 24 November 2021

[39] OECD: OECD/INFE 2020 International Survey of Adult Financial Literacy. 2020 ,

www.oecd.org/financial/education/launchoftheoecdinfeglobalfinanciallitera cysurveyrep.htm, downloaded: 24 November 2021

[40] Jappelli, T.; Padula, M.: Investment in financial literacy and saving decision. Journal of Banking and Finance, 2013, No. 37, pp. 2779-2792

[41] Kotlikoff, L. J,; Bernheim, B. D.: Household financial planning and financial literacy. Cambridge, MA: MIT Press, 2001, pp. 427-478

[42] Kálmán, B.; Bárczi, J.; Zéman, Z.: A Covid-19 első hullámának hatása a gazdasági felsőoktatásban tanuló hallgatók pénzügyi biztonságára, Pénzügyi Szemle, 2021, No. 3, pp. 368-389

[43] Bruno, P.; Doshi, N.; Maxwell, M. N.; Bollard, A.; Konstantynova, N.; Segev, I.: The Future of US Retail Banking Distribution Retail Banking Insights,

Mc.Kinsey\&Company, https://www.mckinsey.com/ /media/McKinsey/dotcom/client_service/Fina ncial\%20Services/Latest\%20thinking/Consumer\%20and\%20small\%20busi ness\%20banking/Future_of_US_retail_banking_distribution.ashx, downloaded: 14 October 2020

[44] Hatami, A.: The future of banking: four scenarios. 2015, https://medium.com/@a_hatami/the-future-of-banking-a607c121ff9d, downloaded: 12 April 2021

[45] Kerényi, Á.; Müller, J.: Szép új digitális világ? - A pénzügyi technológia és az információ hatalma. Hitelintézeti Szemle, 2019, Vol. 18, No. 1, pp. 5-33

[46] National Bank of Hungary: Fintech és digitalizációs jelentés, 2020, https://www.mnb.hu/kiadvanyok/jelentesek/fintech-es-digitalizaciosjelentes/fintech-es-digitalizacios-jelentes-2020-aprilis, downloaded: 11 October 2021

[47] Accenture: 2019 Accenture Global Financial Services Consumer Study, https://www.accenture.com/_acnmedia/pdf-95/accenture-2019-globalfinancial-services-consumer-study.pdf, downloaded: 14 October 2020

[48] Accenture: 2020 Accenture Global Financial Services Consumer Study, https://www.accenture.com/_acnmedia/PDF-144/Accenture-InfographicBanking-Consumer-Study-2020.pdf, downloaded: 14 October 2020

[49] National Bank of Hungary: Fintech és digitalizációs jelentés, 2021, https://www.mnb.hu/kiadvanyok/jelentesek/fintech-es-digitalizaciosjelentes/fintech-es-digitalizacios-jelentes-2021-majus, downloaded: 11 October 2021 